\title{
A comparative study of 5 different extraction methods for systematic toxicological analysis of serum
}

\author{
Étude comparative de cinq méthodes \\ d'extraction différentes pour l'analyse \\ toxicologique systématique du sérum
}

Serge SCHNEIDER, Estelle PANAROTTO, Robert WENNIG

Laboratoire National de Santé, Division de Toxicologie, Centre Universitaire de Luxembourg, 162a, avenue de la Faïencerie - L - 1511 LUXEMBOURG - Tél : +(352) 466644 480, 474 E-mail : schneide@cu.lu, wennig@cu.lu

(Reçu le 15 octobre 2001 ; accepté le 10 novembre 2001)

\section{SUMMARY}

Two liquid - liquid (LLE) and three solid phase (SPE) extraction methods for the GC/MS analysis of serum samples have been evaluated as a function of time, repetability and chromatographic cleanness of the extracts. 45 common drugs (representative for the following pharmacological classes: sedatives, antidepressants, opiates, barbiturates, analgesics, anti-epileptics and beta blockers) have been studied. Very clean extracts could be obtained by "back-extraction" of alkaline extracts (LLE "A" method) but at the price of low extraction yields and the loss of acidic substances. The more straightforward alkaline extraction ("LLE B" method) was fast but the extracts contained many endogenous molecules. The SPE methods (using Chromabond, Certify and Clean Screen cartridges) all gave good extraction yields with relatively low standard deviation but they are time consuming and thus may be mainly interesting when time is not a limiting factor.

\section{KEY-WORDS}

Solid phase extraction, liquid/liquid extraction, GC/MS analysis.

\begin{abstract}
RÉSUMÉ
Deux méthodes d'extraction liquide-liquide (LLE) et trois méthodes d'extraction en phase solide (SPE) pour des analyses d'échantillons de sérums par CGP/SM ont été évaluées en fonction du temps, de la répétabilité et de la propreté des chromatogrammes obtenus avec les extraits. 45 médicaments usuels (représentatifs de classes pharmacologiques suivantes : sédatifs, antidépresseurs, opiacés, barbituriques, analgésiques, antiépileptiques et béta-bloquants) ont été testés. Des extraits très propres ont été obtenus par ré-extraction d'extraits alcalins (méthode LLE " $A$ ") mais au prix de rendements d'extraction faibles et de la perte des substances acides. L'extraction alcaline directe (méthode LLE " $B$ ") est rapide, mais les extraits contenaient de nombreuses molécules endogènes. Les méthodes SPE (faites sur colonnes Chromabond, Certify et Clean Screen) ont toutes donné de bons rendements d'extraction et des coefficients de variation relativement faibles mais elles sont lentes et sont probablement plus intéressantes pour les investigations où le temps n'est pas un facteur limitant.
\end{abstract}

\section{MOTS-CLÉS}

Extraction en phase solide, extraction en phase liquide/liquide, analyses CPG/SM. 


\section{Introduction}

High Performance Liquid Chromatogrpaphy - Diode Array Detection (HPLC-DAD) and Gas Chromatography/Mass Spectrometry (GC/MS) are the techniques which today are established in most laboratories for routine toxicological screening $(1,2)$.

Reverse phase-HPLC coupled to UV-DAD gives highly repeatable results and limits of detection (LOD) and limits of quantification (LOQ) sufficiently low to allow detection and quantification of many drugs frequently encountered in acute intoxications (3). Its limitations however are the similarity of many UV spectra (benzodiazepines, tricyclic antidepressants, ...), relatively low separation capacity of the columns (frequent overlapping of peaks) and the impossibility to detect drugs not absorbing in the UV range (e.g. valproic acid, meprobamate).

GC/MS on the other side generally gives good separation and the fragmentation pattern observed in MS spectra generally allows unambiguous identification of the compounds detected. Serum analysis by GC/MS however is of limited popularity as endogenous biomolecules, present in high concentration, often interfere with the drugs that are to be detected. The work-up of serum in order to carry out GC/MS analysis is always a compromise between (a) pure extracts but low extraction yields with the risk of not detecting important xenobiotics and (b) high extraction yields but presence of endogenous compounds with the risk of chromatographic interferences.

The aim of the present work was to compare the analytical performances of 5 different extraction methods [two involving liquid-liquid extraction (LLE) and three involving solid phase extraction (SPE) using commercially available cartridges for serum analysis by GC/MS. A general overview of the use of SPE in systematic toxicological analysis has been published (4). 45 drugs frequently encountered in clinical and forensic toxicological analysis have been investigated by using spiked serum samples. Evaluation of the extraction methods will be discussed as a function of (a) the time needed for the extraction procedure, (b) the extraction yield (carried out on a limited number of drugs) and (c) the cleanness of the extracts e.g. presence of endogenous substances interfering with the xenobiotics

\section{Materials}

\section{Chemicals and reagents}

Ethyl acetate, methanol, hexane, dichloromethane and 2-propanol were purchased from Lab-Scan analytical sciences (Labscan Ltd., Dublin, Ireland). 1,2-dichloroethane was obtained from Sigma (Steinheim, Germany). Acetic acid, concentrated $\mathrm{HCl}, \mathrm{NaOH}$ and pyridine were obtained from UCB (Louvain, Belgium). Acetic anhydride was purchased from Fluka (Buchs, Switzerland). Ammonium sulphate and potassium dihydrogenophosphate were obtained from Merck (Darmstadt, Germany).

Chromabond $\mathrm{C} 18 \mathrm{ec}$ cartridges were purchased from Macherey-Nagel (Hoerdt, France), Certify cartridges were purchased from Varian (Zaventem, Belgium) and Clean Screen cartridges were purchased from SDS (Seltz, France).

\section{Instrumentation}

Electron impact (EI) mass spectra were recorded with a mass selective detector from Hewlett-Packard (5971 A-Series II) fitted with a $12 \mathrm{~m}$ Ultra-2 capillary column from HP with $0.2 \mathrm{~mm}$ internal diameter and $0.33 \mathrm{~mm}$ film thickness. Helium was used as carrier gas at a flow rate of $0.5 \mathrm{ml} / \mathrm{min}$. The ionisation voltage was $70 \mathrm{eV}$, the injector temperature was $260^{\circ} \mathrm{C}$ and the detector temperature was $280^{\circ} \mathrm{C}$. The initial column temperature was $70^{\circ} \mathrm{C}\left(2 \mathrm{~min}\right.$.) ; ramp $20^{\circ} \mathrm{C} / \mathrm{min}$; final temperature $280^{\circ} \mathrm{C}(11.5 \mathrm{~min})$. The MS spectra were recorded in scan mode from 50 - 650 Thompson. Injection was in the splitless mode.

\section{Extraction methods}

\section{1) Method 1 : LLE "A" (back-extraction)}

To $0.5 \mathrm{ml}$ of the spiked serum specimen were added $0.5 \mathrm{ml}$ of a saturated ammonium sulphate solution, $0.5 \mathrm{ml}$ of $\mathrm{pH} 9.5$ ammonium buffer and $5 \mathrm{ml}$ of extraction solvent (hexane/dichloromethane/2-propanol, $60 / 40 / 2, \mathrm{v} / \mathrm{v} / \mathrm{v})$. The solution was mechanically agitated for 5 minutes and centrifuged for 3 minutes at $4000 \mathrm{rpm}$. The layers were separated then $3 \mathrm{ml}$ of water and $50 \mu \mathrm{l}$ of $\mathrm{HCl} 12 \mathrm{M}$ were added to the organic layer. After agitation and centrifugation as above, the aqueous phase was neutralised with $50 \mu 1 \mathrm{NaOH} 12 \mathrm{M}$ and $1 \mathrm{ml}$ of $\mathrm{pH} 9.5$ ammonium buffer was added. Extraction of this layer with the same solvent as above was then carried out.

After evaporation of the organic layer at $40^{\circ} \mathrm{C}$ under a stream of nitrogen, the residue was acetylated using $50 \mu \mathrm{l}$ of pyridine and $50 \mu \mathrm{l}$ of acetic acid anhydride for 20 minutes at $90^{\circ} \mathrm{C}$. The mixture was evaporated at $40^{\circ} \mathrm{C}$ with nitrogen and the residue was dissolved in $100 \mu \mathrm{l}$ of ethyl acetate / methanol ( $9 / 1 \mathrm{v} / \mathrm{v}) .1 \mu \mathrm{l}$ of this solution was injected into the GC/MS system. 


\section{2) Method 2 : LLE "B"}

The initial method has been described by Brau et al. (5). It has been used with some modifications.

To $0.5 \mathrm{ml}$ of serum were added $1 \mathrm{ml}$ of $\mathrm{pH} 9.5$ ammonium buffer, $0.5 \mathrm{ml}$ of a saturated ammonium sulphate solution and $5 \mathrm{ml}$ of the extraction solvent consisting in 1,2-dichloroethane / dichloromethane / hexane / 2-propanol $(96 / 52 / 132 / 20, v / v / v / v)$. The mixture was agitated for 5 minutes and centrifuged for 5 minutes at $5000 \mathrm{rpm}$. Acetylation and final work up was carried out as described for method 1.

\section{3) Method 3 : SPE Chromabond C18ec (250 mg)}

Conditioning of the cartridges was carried out with $1 \mathrm{ml}$ of methanol followed by $1 \mathrm{ml}$ of deionised water. $0.5 \mathrm{ml}$ of spiked serum was adjusted to $\mathrm{pH} 9.5$ with $0.5 \mathrm{ml}$ ammonium buffer and deposited on the cartridge. The cartridge was then washed twice with $0.5 \mathrm{ml}$ of a $\mathrm{H}_{2} \mathrm{O} /$ methanol $(1 / 3, \mathrm{v} / \mathrm{v})$ mixture and once with $0.5 \mathrm{ml}$ of $\mathrm{n}$-hexane. It was then centrifuged for $1 \mathrm{~min}$ at $5000 \mathrm{rpm}$. Drugs were eluted with $2 \times 750 \mathrm{ul}$ of methanol / dichloromethane $(1 / 1, v / v)$. Acetylation and final work up was carried out as described for method 1.

\section{4) Method 4 : SPE Certify (130 mg)}

The cartridges were conditioned by $2 \mathrm{ml}$ of methanol followed by $2 \mathrm{ml}$ of pH 6.0 phosphate buffer. $0.5 \mathrm{ml}$ of the serum was then deposited on the cartridge. The cartridge was washed successively with $\mathrm{pH} 6.0$ phosphate buffer $(1 \mathrm{ml})$, a mixture of $\mathrm{pH} 6.0$ phosphate buffer / methanol $(8 / 2, \mathrm{v} / \mathrm{v})(1 \mathrm{ml})$ and $1 \mathrm{M}$ acetic acid $(1 \mathrm{ml})$, then dried under vacuum for 2 minutes. Washing was continued by passing $1 \mathrm{ml}$ of hexane over the cartridge, drying under vacuum for $5 \mathrm{~min}$ and centrifugation at $5000 \mathrm{rpm}$ for 1 minute. Drugs were eluted using $2 \mathrm{ml}$ of a mixture of dichloromethane / 2-propanol / ammonium hydroxyde $(85 / 15 / 2, \mathrm{v} / \mathrm{v} / \mathrm{v})$. Acetylation and final work-up was carried out as described for method 1.

\section{5) Method 5 : SPE Clean Screen (200 mg)}

Conditioning of the cartridges was carried out using successively $3 \mathrm{ml}$ of methanol, $3 \mathrm{ml}$ of deionised water and $1 \mathrm{ml}$ of $\mathrm{pH} 6.0$ phosphate buffer. $0.5 \mathrm{ml}$ of the serum was adjusted to $\mathrm{pH} 6.0$ by adding $0.5 \mathrm{ml}$ of phosphate buffer and deposited on the cartridge. The cartridge was washed with $3 \mathrm{ml}$ of deionised water and $1 \mathrm{ml}$ of acetic acid $1 \mathrm{M}$ and then dried for 5 minutes under vacuum. Washing was carried out by $2 \mathrm{ml}$ of hexane followed by drying under vacuum for 2 minutes. Acidic and neutral substances were eluted by a mixture consisting of hexane/ethyle acetate $(1 / 1, v / v)$.
The cartridge was then washed with $3 \mathrm{ml}$ of methanol and dried for 5 minutes under vacuum. Alkaline substances were eluted using a mixture of dichloromethane / 2-propanol / ammonium hydroxide (78/20/2, $\mathrm{v} / \mathrm{v} / \mathrm{v})$. The elutes were mixed and evaporated under a flux of nitrogen. Acetylation and final work up was carried out as described in for method 1.

\section{6) Determination of extraction yield}

Extraction yields (E.Y.) have been determined for alimemazine, amitriptyline, fluoxetine, methadone, morphine and diazepam, using methaqualone as internal standard. In order to be in the best possible conditions, we used rather high concentrations of drugs and internal standard: alimemazine $1.0 \mathrm{mg} / \mathrm{L}$, amitriptyline $2.0 \mathrm{mg} / \mathrm{L}$, fluoxetine $2.0 \mathrm{mg} / \mathrm{L}$, methadone $1.0 \mathrm{mg} / \mathrm{L}$, morphine $1.0 \mathrm{mg} / \mathrm{L}$, diazepam $1.0 \mathrm{mg} / \mathrm{L}$, methaqualone $10 \mathrm{mg} / \mathrm{L}$.

Each extraction method was performed 5 times using spiked serum specimens and methaqualone as internal standard (A). Each extraction procedures was then performed once more using serum spiked with methaqualone only. In these cases, the drugs were added to the serum extracts at a concentration corresponding to an extraction yield of $100 \%$ (B). The extraction yield was calculated as follows :

[TIC (A) drug / TIC (A) methaqualone] / [TIC (B) drug / TIC (B) methaqualone] $\times 100$

(TIC $=$ total ion current).

\section{Results and Discussion}

The five extraction methods were chosen as a function of the specific advantages they were supposed to offer. Typical chromatograms obtained by the 5 extraction procedures, from the same spiked serum specimen are presented in figure 1.

The method "LLE A" involves 2 extraction steps. It has been designed in order to eliminate the maximum of acidic substances, i.e. fatty acids and cholesterol which are usual interfering compounds in GC/MS. The method thus has the theoretical advantage of providing clean chromatograms but has the drawback that most of the acidic substances will be lost. The "LLE B" method involves a single extraction step in alkaline condition; it is the fastest of all the methods tested. The extraction solvent has been optimised for alkaline substances, acidic drugs bring generally present at high concentrations and a relatively low extraction yield still being sufficient for their detection and also for semi-quantitative estimation if the adequate internal standard is used. 

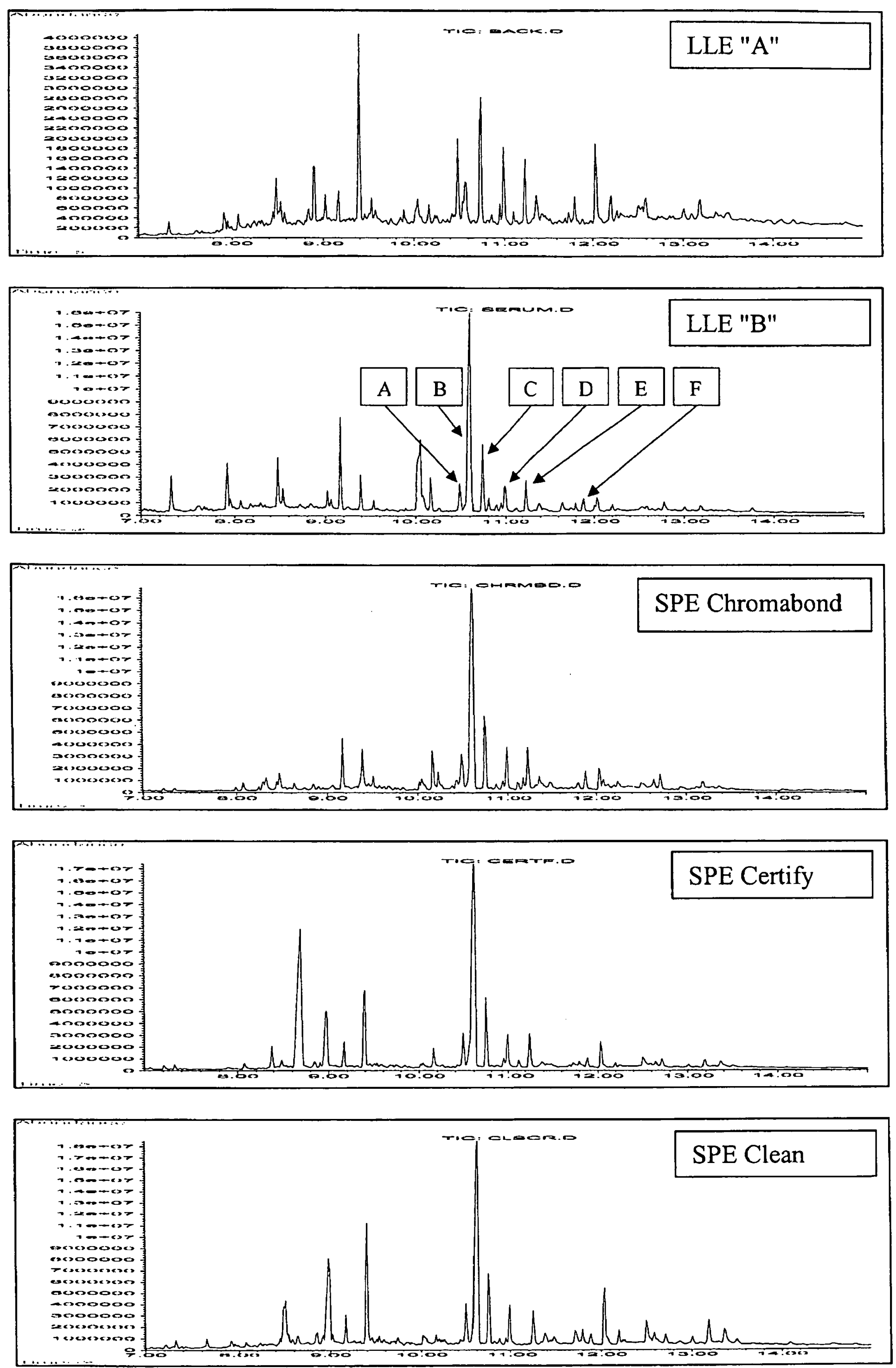

Figure 1 : Typical chromatograms obtained by the 5 different extraction procedures (zoom $7-15$ minutes, $A=$ methadone, $B=$ methaqualone, $C=$ amitriptyline, $D=$ fuoxetine, $E=$ alimemazine, $F=$ diazepam, $G=$ diacetylmorphine). 
The extraction mixture has the advantage of being of lower density than the serum layer making its recovery easy and still possesses the extraction quality of chlorinated solvents.

The three SPE methods show important differences. The SPE cartridges used were an "end-capped" C18 from Chromabond and two different "mixed" cartridges (Certify and Clean Screen) with 50\% C8 modified silica (using non-polar Van de Waals forces for retention) and $50 \%$ ionic groups (using polar cation-anion interactions for retention). These cartridges are generally recommended for the extraction of drugs and drugs of abuse from biological matrices. SPE is more time consuming than LLE but cleaner extracts can be obtained. The Certify and Clean Screen cartridges gave interesting low abundances in endogenous fatty acids and still good extraction yields for the drugs tested. The methaqualone peak $(10 \mathrm{mg} / \mathrm{L}$, retention time $10.40 \mathrm{~min})$ is the most important peak in these chromatograms.

The approximate time needed for the extraction (including evaporation of the solvent $(10 \mathrm{~min})$ and derivatisation procedure $(20 \mathrm{~min})$ ) to be completed are given in table I. The "LLE B" method is the fastest and the easiest to perform. This may be an important consideration in acute intoxication cases where time is an important factor. The "Clean Screen" extraction procedure is the most time consuming because two different elution steps (one for alkaline and one for acidic and neutral drugs) are used.

The extraction yields are given in table II.
Back-extraction (method "LLE A") gave very low extraction yields for morphine and nordazepam. This may be explained by the amphoteric nature of these compounds. For example, the $\mathrm{pKa}$ values for morphine are 7.93 (tertiary amine) and 9.63 (phenolic hydrogen). At the working $\mathrm{pH}$ of 9.5 , an important fraction of morphine is in the ionic form, thus being soluble in the aqueous layer and diminishing the extraction yield.

Much better results were obtained by the "LLE B" method with extraction yields varying between $33.3 \%$ (morphine) and $74.0 \%$ (alimemazine and diazepam). The presence of non-polar $n$-hexane in the extraction phase was probably responsible for the relatively high extraction yield of diazepam. The extraction yield of morphine was better for "LLE B" because the method only consists of 1 extraction step as compared to 3 extraction steps in "LLE A". A drawback of the "LLE $\mathrm{A}^{\prime \prime}$ method is the high RSD values as compared to the other methods. Relatively constant and high extraction yields (above $65 \%$ ) were obtained using SPE methods. RSD values obtained by Chromabond and Certify cartridges are higher for most substances than those obtained by Clean Screen cartridges, which might be explained by non-homogeneous extraction phase support.

A limiting factor of GC/MS analysis of serum extracts often is the presence of large amounts of endogenous biomolecules which overlap with relatively small amounts of xenobiotics. The extraction procedure aims at eliminating these interfering substances. The relative amounts of the most important endogenous molecules

Tableau I : Approximate time needed to complete the extractions (including evaporation and derivatisation steps).

\begin{tabular}{|c|c|c|c|c|c|}
\hline & LLE A & LLE B & Chromabond & Certify & Clean-Screen \\
\hline Time (min) & 65 & 45 & 65 & 70 & 95 \\
\hline
\end{tabular}

Tableau II : Extraction yield of selected drugs from spiked serum $(E Y=$ extraction yield, $R S D=$ relative standard deviation, $n=5$ ).

\begin{tabular}{|c|c|c|c|c|c|c|c|c|c|c|}
\hline & \multicolumn{2}{|c|}{ LLE A } & \multicolumn{2}{c|}{ LLE B } & \multicolumn{2}{c|}{ Chromabond } & \multicolumn{2}{c|}{ Certify } & \multicolumn{2}{c|}{ Clean-Screen } \\
\hline & $\begin{array}{c}\text { EY } \\
(\%)\end{array}$ & $\begin{array}{c}\text { RSD } \\
(\%)\end{array}$ & $\begin{array}{c}\text { EY } \\
(\%)\end{array}$ & $\begin{array}{c}\text { RSD } \\
(\%)\end{array}$ & $\begin{array}{c}\text { EY } \\
(\%)\end{array}$ & $\begin{array}{c}\text { RSD } \\
(\%)\end{array}$ & $\begin{array}{c}\text { EY } \\
(\%)\end{array}$ & $\begin{array}{c}\text { RSD } \\
(\%)\end{array}$ & $\begin{array}{c}\text { EY } \\
(\%)\end{array}$ & $\begin{array}{c}\text { RSD } \\
(\%)\end{array}$ \\
\hline Alimemazine & 48.7 & 12.8 & 74.0 & 28.9 & 94.6 & 21.2 & 94.4 & 11.3 & 76.2 & 7.6 \\
Amitriptyline & 33.5 & 20.5 & 82.6 & 28.5 & 83.7 & 12.2 & 85.7 & 12.1 & 77.2 & 2.3 \\
Fluoxetine & 43.6 & 20.2 & 82.2 & 33.4 & 89.0 & 14.6 & 88.3 & 9.8 & 67.1 & 8.2 \\
Methadone & 49.9 & 10.9 & 89.5 & 20.2 & 109.5 & 34.9 & 77.0 & 9.8 & 79.5 & 10.6 \\
Morphine & 7.1 & 9.3 & 33.3 & 46.1 & 94.8 & 8.3 & 65.6 & 26.3 & 76.1 & 10.6 \\
Diazepam & 9.7 & 10.7 & 74.0 & 28.0 & 107.8 & 19.4 & 87.3 & 14.4 & 60.4 & 5.9 \\
\hline
\end{tabular}


Tableau III : Drugs used for the comparative study of extraction methods. $(C=$ Chromabond, $D=$ Certify, $E=$ Clean Screen, “" = not detected, " +" = low intensity peak, " ++" = high intensity peak).

\begin{tabular}{|c|c|c|c|c|c|c|c|}
\hline Drug & $\begin{array}{l}\text { Therapeutic } \\
\text { range }(\mathrm{mg} / \mathrm{L})\end{array}$ & $\begin{array}{l}\text { Conc. } \\
(\mathrm{mg} / \mathrm{L})\end{array}$ & LLE A & LLE B & $\mathbf{C}$ & D & $\mathbf{E}$ \\
\hline Alimemazine & $0.05-0.40$ & 0.40 & ++ & ++ & + & + & - \\
\hline Alprazolam & $0.02-0.06$ & 1.00 & - & - & - & - & - \\
\hline Alprenolol & $0.05-0.10$ & 1.00 & ++ & ++ & ++ & ++ & ++ \\
\hline Amitriptyline & $0.05-0.20$ & 0.20 & ++ & ++ & ++ & ++ & ++ \\
\hline Atenolol & $0.20-0.60$ & 1.00 & - & - & - & - & - \\
\hline Bromazepam & $0.08-0.17$ & 2.00 & + & - & ++ & - & - \\
\hline Carbamazepine & $4.50-9.00$ & 5.00 & - & ++ & + & + & ++ \\
\hline Clomipramine & $0.05-0.15$ & 0.20 & - & ++ & + & + & - \\
\hline Codeine & $0.01-0.05$ & 2.00 & ++ & ++ & ++ & + & - \\
\hline Desipramine & $0.08-0.25$ & 0.25 & + & + & ++ & + & + \\
\hline Diazepam & $0.13-0.75$ & 0.20 & - & ++ & ++ & + & + \\
\hline Diclofenac & $0.05-0.50$ & 3.00 & - & + & ++ & + & + \\
\hline Diltiazem & $0.05-0.30$ & 1.00 & + & + & + & + & + \\
\hline Diphenhydramine & $0.03-0.11$ & 1.00 & + & ++ & + & + & ++ \\
\hline Dosulepine & $0.05-0.15$ & 0.40 & ++ & ++ & ++ & + & ++ \\
\hline Doxepine & $0.10-0.25$ & 0.25 & ++ & ++ & + & + & ++ \\
\hline Doxylamine & $0.07-0.20$ & 1.00 & + & ++ & - & - & ++ \\
\hline EDDP & 0.10 & 0.50 & - & - & - & - & - \\
\hline Ethosuximide & $40.0-100.0$ & 25.00 & - & + & + & + & ++ \\
\hline Flunitrazepam & $0.01-0.02$ & 1.00 & - & + & + & + & - \\
\hline Fluoxetine & $0.09-0.50$ & 0.50 & ++ & ++ & ++ & ++ & ++ \\
\hline Imipramine & $0.05-0.15$ & 0.20 & + & ++ & ++ & + & + \\
\hline Levomepromazine & $0.03-0.15$ & 0.10 & + & + & + & + & - \\
\hline Lorazepam & $0.02-0.30$ & 1.00 & - & + & + & + & - \\
\hline Lormetazepam & $0.00-0.01$ & 1.00 & - & ++ & ++ & ++ & ++ \\
\hline Meprobamate & $10.0-25.0$ & 20.00 & + & + & - & + & + \\
\hline Methadone & $0.10-0.75$ & 1.00 & ++ & ++ & ++ & + & ++ \\
\hline Metoprolol & $0.10-0.60$ & 1.00 & + & + & + & + & + \\
\hline Morphine & $0.08-0.12$ & 0.20 & - & + & + & - & + \\
\hline Nordazepam & $0.20-0.80$ & 1.00 & - & + & + & + & + \\
\hline Nortriptyline & $0.12-0.25^{(*)}$ & 0.25 & + & + & ++ & + & ++ \\
\hline Oxazepam & $1.00-2.00$ & 2.00 & - & - & ++ & + & - \\
\hline Paracetamol & $10.0-25.0$ & 10.00 & - & + & + & + & + \\
\hline Phenobarbital & $20.0-40.0$ & 30.00 & + & + & - & ++ & ++ \\
\hline Phenytoïn & $8.0-20.0$ & 5.00 & - & + & + & ++ & + \\
\hline Pholcodine & 0.50 & 1.00 & + & + & + & - & + \\
\hline Promazine & $0.10-0.40$ & 0.10 & - & + & + & ++ & - \\
\hline Propoxyphene & $0.10-0.75$ & 1.00 & + & ++ & ++ & + & ++ \\
\hline Propranolol & $0.05-0.15$ & 1.00 & - & + & + & + & + \\
\hline Prothipendyl & $0.05-0.20$ & 0.50 & + & + & ++ & ++ & ++ \\
\hline Sulpiride & $0.04-0.60$ & 0.50 & - & + & ++ & + & - \\
\hline Temazepam & $0.30-0.90$ & 0.40 & - & ++ & + & + & + \\
\hline Thioridazine & $0.20-1.00$ & 1.00 & - & + & + & + & + \\
\hline Trazodone & $0.07-1.70$ & 2.00 & - & + & - & - & - \\
\hline Verapamil & $0.09-0.35$ & 1.00 & - & - & - & - & - \\
\hline
\end{tabular}


(myristic acid, palmitic acid, linoleic acid and cholesterol) are highest for the "LLE B" method and lowest in the "LLE A" method. Intermediate results are obtained by the SPE methods (all extractions have been performed on the same serum). The absolute amounts of fatty acids recovered are of course depending on the amount present before extraction and these vary from one serum to the other.

In table III are represented all the 45 drugs tested by the 5 different extraction methods. The therapeutic ranges (6) and the concentrations used in this study are given together with an indication of the peak height at the chosen concentration. The concentrations of several of these drugs were chosen above therapeutic levels because they are not easily detected by GC/MS in the full scan mode.

It has to be emphasized that no simple relation exists between a good extraction yield and the peak height of the substance on the chromatogram. Thermal instability, non-volatility of the substance, low ionisation yield or overlapping of different peaks may significantly reduce the detectability of a drug.

\section{Conclusion}

The choice of an extraction method for a "general unknown" screening is always a compromise between rapidity and quality (cleanness) of the extracts. Of the five methods tested in this paper, the "LLE A" method provided the cleanest extracts but at the cost of low extraction yields and of loosing acidic and neutral substances. Paracetamol, valproic acid, salicylic acid and meprobamate for example may not be detected at low concentration. This method thus is of interest if small concentrations of alkaline xenobiotics are to be detected and if the time factor is not crucial. The "LLE B" method is fast and high extraction yields are obtained. This is at the cost of the presence of relatively high amounts of endogeneous biomolecules. The method seems most interesting in acute intoxication cases where detection and quantification of alkaline and acidic drugs are to be obtained quickly. As "LLE A", the three SPE methods are relatively labour intensive. Their advantage over LLE methods is a good repetability and relatively clean extracts.

\section{References}

1. Elliot S. P. and Hale K. A., Applications of an HPLCDAD Drug-Screening System Based on Retention Indices and UV Spectra. J. Anal. Toxicol. $1998 ; 22$ : 279-89.

2. Maurer H. H., Systematic toxicological analysis of drugs and their metabolites by gas chromatography-mass spectrometry. J. Chromatogr. $1992 ; 580: 3-41$.

3. Gaillard Y. and Pépin G., Use of High-Performance Liquid Chromatography with Photodiode-Array Detection for the Creation of a 600-Compound Library. Application to Forensic Toxicology. J. Chromatogr. A. $1997 ; 763: 149-63$.
4. Franke J. P. and de Zeeuw R. A., Solid-Phase Extraction Procedures in Systematic Toxicological Analysis. J. Chromatogr. B. 1998 ; 713 : 51-9.

5. Brau M., Vanbinst R., Hassoun A. and Wallemacq P. E., Simultaneous detection and quantification of acidic and basic drugs in serum toxicological screening: Use of ionpairing technique in liquid-liquid extraction. Acta Clinica Belgica. Special issue 1, 1999 : 74-8.

6. D. R. A. Uges. Tiaft Bulletin. $26 \mathrm{nb} 1$ supplement. $1996: 5-34$. 